\title{
EFFECT OF SUPPLEMENTATION OF OMEGA-3 FATTY ACIDS ON BLOOD PARAMETERS AND SEMEN QUALITY OF FRIESIAN BULLS
}

\author{
Mohamed A. Abu El-Hamd ${ }^{1 *}$, Abd Salam M. Metwally², Mohamed M. Hegazy', \\ Zahya R. Ghallab², Ola A. Elateeqy²
}

${ }^{1}$ Animal Production Research Institute, Agricultural Research Center, Dokki, Egypt, ${ }^{2}$ Department of Animal Production, Faculty of Agriculture, Kafrelsheikh University, 33516, Egypt

*Corresponding author E-mail: abuelhamd68@yahoo.com

\begin{abstract}
The aim of this work was to evaluate the effects of flaxseed oil supplementation as a source of omega- 3 fatty acids (OFA) on some blood parameters, semen quality and testosterone level in male Frisian bull. A total of 30 Friesian bulls $(14.2 \pm 0.16$ month of age and $265 \pm 15 \mathrm{~kg}$ body weight) were divided into three equal groups according to age and live body weight. Bulls in the $1^{\text {st }}$ group (G1) were supplemented with $2 \%$ dray matter intake (DMI) flaxseed oil as a source of OFA, while those in $2^{\text {nd }}$ group were supplemented with $4 \%$ DMl flaxseed oil as a source of OTA at 14 to 21 months of age (G2). Bulls in the $3^{\text {rd }}$ group were fed a basal diet and considered as a control group (G3). The obtained results revealed that OFA administrated animals had a significant $(P<0.05)$ inducing effect on serum levels of total protein, globulin, glucose, high density lipoprotein (HDL) and triglyceride compared to the control group. No significant changes were noticed in albumin levels among the three groups. However, the levels of total cholesterol, urea and low density lipoprotein (LDL) were significantly lower in bulls received OFA than the control group. Omega-3 fatty acids treatment has a significant positive effect on the semen characteristics and lower abnormality in G2 and G3 than in G1. G2 and G3 also showed a significant higher intact spermatozoa cell membrane than in G3 by about 9.68 and $10.84 \%$, respectively. Omega-3 treatment significantly increased blood testosterone levels to be $23,78 \%$ in G2 and $31.82 \%$ in G3 higher than that of the control. In conclusion, dietary supplementation with omega-3 in male Frisian ration improved semen quality and reproductive potentiality as well as testosterone level.
\end{abstract}

Key words: Frisian bull; omega-3 fatty acids; testosterone and semen quality

\section{Introduction}

Bull fertility has a high economic importance in cattle artificial fertilization (AI) industry as semen high quality is crucial for success-ful AI. Flaxseed oils are an excellent as a source of $\alpha$ - linolenic acid, a member of the omega-3 fatty acids (OFA) (1). The fraction of flaxseed oil is approximately 0.55 omega- $3 \alpha$ linolenicacid (2). OFAs are able to lower the risks of some diseases $(1,3)$. Alpha linolenic acid, an essential OFA, is a precursor of eicosapentaenoic acid (EPA), which in turn is a precursor for the formation of eicosanoids. Eicosanoids are hormone-like compounds that play an essential role in immunity faction. Some 
study reported that EPA can elongate further to docosahexanoic acid (DHA), an OFA that is essential for cell membrane integrity and brain health (4).

Prostaglandins (PG) may play an important role in reproductive performance, especially semen quality (5). Arachidonic acid is a subsequent production of $\mathrm{PG}$ and is involved on synthesis of the steroid hormone (6). Total sperm number (7) and sperm motility (8) were improved following administration of fish oil to boars. On the other hand, semen characteristics were negatively affected after treatment with omega-6 in humans (9). High concentrations of polyunsaturated fatty acid (PUFA) in sperm membranes may improve semen quality after supplementation of long-chain omega-3 (5).

The aim of this work was to study the effect of OFA on some blood parameters, testosterone level and semen quality in Friesian bull.

\section{Materials and methods}

The experiment was performed at Sakha Experimental Station, Kafr-Elsheikh Governorate located in the Northern part of the Nile delta, at Animal Production Research Institute (APRI), Agricultural Research Center, Ministry of Agriculture, Egypt.

\section{Animals}

A total number of 30 Friesian bulls averaging $14.2 \pm 0.16$ month of age and $265 \pm 15 \mathrm{~kg}$ body weight were used in this study. The bulls were randomly classified into three groups (10 each), according to their body wieght and age. Bulls in the $1^{\text {st }}$ group (G1) were supplemented with $2 \%$ DMI flaxseed oil as a source of OFA, while the bulls in the $2^{\text {nd }}$ group were supplemented with 4\% DMI flaxseed oil (G2). Bulls in the $3^{\text {rd }}$ group were fed a basal diet and considered as a control group (G3). All bulls were judged as free of diseases and physical defects genitalia. The experimental animals were kept freely under semi-open sheds and were fed according to the recommendations of Animal Production Research Institute (APRI, 10) throughout the experimental period.

\section{Feeding system and management}

The concentrate feed mixture (CFM) was used in bull feeding in all groups. It was composed of $37.5 \%$ yellow corn, $20 \%$ soybean meal, $15 \%$ corn gluten, $22.5 \%$ wheat bran, $3 \%$ molasses, $0.5 \%$ premix (one $\mathrm{kg}$ of premix contained $3.3 \times$ $10^{6} \mathrm{IU}$ vit. A; $3.3 \mathrm{~g}$ vit. $\mathrm{E} ; 3.3 \times 10^{6} \mathrm{IU}$ vit. D3; 0.33 g vit. $\mathrm{K} ; 0.33 \mathrm{~g}$ vit. $\mathrm{B} 1 ; 1.33 \mathrm{~g}$ vit. $\mathrm{B} 2 ; 6.67$ $\mathrm{g}$ vit. $\mathrm{B} 5 ; 0.50 \mathrm{~g}$ vit. $\mathrm{B} 6 ; 3.3 \mathrm{~g}$ vit. B12; $3.3 \mathrm{~g}$ vit. pantothenic acid; $0.33 \mathrm{~g}$ folic acid; 16.67mg Biotin; 166.67 g Cholin; 1g Copper; $10 \mathrm{~g}$ Iron; $13.3 \mathrm{~g} \mathrm{Mn;} 15 \mathrm{~g} \mathrm{Zn;} 0.1 \mathrm{~g}$ iodin; 0.03 g Se and carrier $\mathrm{CaCO}_{3}$ to $1 \mathrm{~kg}$ ) and $1.5 \%$ common salt.

Bulls in all groups were fed equal amounts of diet containing CFM, rice straw and fresh berseem (during winter season) or berseem hay (during summer season) according to the recommendation of the APRI, (10). Allowances for growing dairy bulls based on live body weight. Chemical analysis of representative monthly samples of foodstuffs was analyzed for CP, CF, EE, NFE and ash on DM basis according to the official methods of the A.O.A.C (11). Chemical composition of CFM, rice straw, fresh berseem and berseem hay used in feeding bulls in both groups is shown in Table (1).

\section{Experimental procedures}

Throughout the experimental period, semen samples were collected on all animals twice weekly using an artificial vagina at 18 months of age bulls at time of collection up to 21 months of age. After semen collection, each ejaculate was evaluated for volume, sperm concentration $\left(\mathrm{x} 10^{6} / \mathrm{ml}\right)$ mass motility $(\%)$, live sperm $(\%)$, sperm abnormality (\%) and sperm concentration/ejaculate $\left(\mathrm{x} 10^{6} / \mathrm{ml}\right)$. As well as, sperm cell concentration was directly evaluated according to Barth (12).

The integrity of plasma membrane for the fresh spermatozoa was examined using hypoosmotic swelling (HOS) test (13). The HOS solution at a concentration of $100 \mathrm{mOsm} / \mathrm{kg}$ was prepared by mixing $0.49 \mathrm{~g}$ of sodium citrate and $0.9 \mathrm{~g}$ fructose with $100 \mathrm{ml}$ distilled water. In brief, $250 \mu$ of diluted semen were added to 
$1 \mathrm{ml}$ of the pre-warmed HOS solution and incubated for $60 \mathrm{~min}$ at $37^{\circ} \mathrm{C}$. A volume of $5 \mu \mathrm{l}$ from each sample was put on clean and warm, microscope slide and were examined at $\mathrm{x} 400$. Spermatozoa were counted 200 per sample and the indicative of intact plasma membrane were also determined.

\section{Blood sampling}

Blood samples were monthly collected during the experimental period in clean test tubes via the jugular vein from all the experimental bulls and were centrifuged at $3000 \mathrm{rpm}$ for 10 minutes. The obtained serum was keep at $-20^{\circ} \mathrm{C}$ until determination of testosterone concentration.

\section{Testosterone assay}

Total and free serum testosterone assay was conducted by radio immune assay method (RIA) using Pontex 335 kit $\left(I^{125}\right)$. Total testosterone included free testosterone and that bound to sex steroid binding globulin hormone, albumin, corticosteroid binding globulin (CBG). The standard curve of testosterone ranged between 0.1 and $25.6 \mathrm{ng} / \mathrm{ml}$.

\section{Biochemical assays}

Serum biochemical parameters (total protein, globulin, glucose, cholesterol, triglyceride, HDL and LDL) were done using commercial kits (Diagnostic System Laboratories, Inc., USA) and as previously described (14-16).

\section{Statistical analysis}

Statistical analyses of data were carried out applying the package of Snedecor and Cochran (17). A factorial design (3 groups $\mathrm{x}$ ages) was used and the statistical model was:

Where:

$$
Y_{i j k}=U+A_{i}+B_{j}+A B_{i j}+e_{i j k} .
$$

$\mathrm{Y}_{\mathrm{ijk}}=$ Observed values;

$\mathrm{U}=$ Overall mean;

$\mathrm{A}_{\mathrm{i}}=$ group;

$\mathrm{B}_{\mathrm{j}}=$ age;

$\mathrm{AB}_{\mathrm{ij}}=$ Interaction due group $\mathrm{x}$ age;

$\mathrm{e}_{\mathrm{ijk}}=$ Random error
The significant differences among means were tested using Duncan Multiple Range Test. Correlation analysis was carried out using computer programmer of SAS system. The percentage values of semen characteristics were tested by arcsine transformation so the means were presented after recalculated from the transformed values to percentages.

\section{Results and discussion}

\section{Serum biochemical parameters in blood}

Flaxseed oil is essential polyunsaturated fatty acids work as constituent of many enzymes which involved of majority of metabolic pathways also was important for metabolism of protein and growth of organ and immunity response. In the current study, flaxseed oil (as a source of OFA) supplementation to Friesian bulls improved the serum content of total protein and lipid profile and immunity markers (Table 2). The addition of flaxseed oil to the bulls ration, significantly $(\mathrm{P}<0.05)$ increased serum HDL, albumin and globulin, and decreased the LDL, cholesterol, TG and blood urea as compared to the control. These results agree with those of other studies where flaxseed oil was reported to reduce total lipids concentration in calves' blood serum (18-22).

Some studies suggested different ways by which PUFA can alter cholesterol concentration $(23,24)$. The synthesis of cholesterol is known to be increased with high PUFA intake $(23,24)$. However, in the current study, the lowering of serum cholesterol with supplementation of flaxseed oil as source of PUFAs could be attributed to the upregulation of LDL receptors (25) and/or the cholesterol redistribution between tissue pools and plasma (23). Flaxseed oil had high percentage of a-linolenic acid about $55 \%$ of oil's total fatty acids $(26,27)$. The diets which are rich in OFA decrease aggregation of platelet also, blood triglycerides and levels of cholesterol, blood clots formation, also, show both antithrombotic and anti-inflammatory effects $(28,29)$. 
Table 1: Chemical analysis of different feedstuffs (on dry matter basis) used in feeding bulls

\begin{tabular}{lllll}
\hline \multirow{2}{*}{ Item } & \multicolumn{4}{l}{ Chemical composition (\%) (on DM basis) } \\
\cline { 2 - 5 } & CFM & $\begin{array}{l}\text { Rice } \\
\text { Straw }\end{array}$ & $\begin{array}{l}\text { Fresh } \\
\text { Berseem }\end{array}$ & $\begin{array}{l}\text { Berseem } \\
\text { Hay }\end{array}$ \\
\hline Dry matter, DM & 90.42 & 89.24 & 15.26 & 88.23 \\
Organic matter, OM & 90.24 & 83.22 & 86.15 & 88.58 \\
Crude protein, CP & 16.04 & 1.59 & 14.71 & 14.41 \\
Crude fiber, CF & 10.96 & 37.21 & 24.9 & 24.67 \\
Other extract, EE & 4.91 & 1.47 & 2.90 & 6.04 \\
Nitrogen free extract, NFE & 56.38 & 42.85 & 43.64 & 43.16 \\
Ash & 9.76 & 16.78 & 13.85 & 11.42 \\
\hline
\end{tabular}

Table 2: Concentration of biochemical parameters in serum as affected by flaxseed oil supplementation

\begin{tabular}{|c|c|c|c|c|}
\hline \multirow{2}{*}{ Item } & \multicolumn{3}{|c|}{ Experimental group } & \multirow{2}{*}{$\pm \mathrm{MSE}$} \\
\hline & G1 & G2 & G3 & \\
\hline Total protein $(\mathrm{g} / 100 \mathrm{ml})$ & $7.68^{\mathrm{a}}$ & $7.55^{\mathrm{a}}$ & $7.23^{\mathrm{b}}$ & 0.03 \\
\hline Albumin $\quad(\mathrm{g} / 100 \mathrm{ml})$ & 3.62 & 3.67 & 3.51 & 0.02 \\
\hline Globulin $\quad(\mathrm{g} / 100 \mathrm{ml})$ & $4.06^{\mathrm{a}}$ & $3.89^{\mathrm{ab}}$ & $3.72^{\mathrm{b}}$ & 0.01 \\
\hline Glucose $\quad(\mathrm{mg} / 100 \mathrm{ml})$ & $69.87^{\mathrm{a}}$ & $71.03^{\mathrm{a}}$ & $61.66^{\mathrm{b}}$ & 2.54 \\
\hline Total cholesterol $(\mathrm{mg} / 100 \mathrm{ml})$ & $166.2^{\mathrm{b}}$ & $163.1^{\mathrm{b}}$ & $187.3^{\mathrm{a}}$ & 3.12 \\
\hline $\begin{array}{l}\text { High density lipoprotein } \\
(\mathrm{mg} / 100 \mathrm{ml})\end{array}$ & $99.50^{\mathrm{b}}$ & $102.4^{\mathrm{a}}$ & $77.39^{\mathrm{c}}$ & 3.80 \\
\hline $\begin{array}{l}\text { Low density lipoprotein } \\
(\mathrm{mg} / 100 \mathrm{ml})\end{array}$ & $67.33^{b}$ & $61.39^{b}$ & $93.99^{\mathrm{a}}$ & 4.62 \\
\hline Triglyceride $(\mathrm{mg} / 100 \mathrm{ml})$ & $37.03^{\mathrm{a}}$ & $38.01^{\mathrm{a}}$ & $28.9^{\mathrm{b}}$ & 0.85 \\
\hline Urea-N (mg/dl) & $26.45^{\mathrm{b}}$ & $24.75^{\mathrm{c}}$ & $31.56^{\mathrm{a}}$ & 2.12 \\
\hline
\end{tabular}

G1and G2: Bulls received flaxseed oil 2 and 4\%/kg DMI, respectively. G3: Control

Data in the raw followed by different letters are significant at $\mathrm{P}<0.05$.

Table 3: Semen quality in Friesian bulls as affected by flaxseed oil supplementation

\begin{tabular}{lcccc}
\hline \multirow{2}{*}{ Item } & \multicolumn{3}{c}{ Experimental group } & \multirow{2}{*}{ \pm MSE } \\
\cline { 2 - 4 } & G1 & G2 & G3 & \\
\hline Ejaculate volume (ml) & $4.13^{\mathrm{a}}$ & $4.24^{\mathrm{a}}$ & $3.74^{\mathrm{b}}$ & 0.03 \\
Sperm cell concentration (x 10 $/ \mathrm{ml})$ & $1.372^{\mathrm{a}}$ & $1.444^{\mathrm{a}}$ & $1.138^{\mathrm{b}}$ & 0.02 \\
Mass motility (\%) & $75.76^{\mathrm{a}}$ & $79.17^{\mathrm{a}}$ & $68.06^{\mathrm{b}}$ & 0.01 \\
Live sperm (\%) & $77.00^{\mathrm{a}}$ & $81.17^{\mathrm{a}}$ & $71.17^{\mathrm{b}}$ & 1.85 \\
Sperm abnormality (\%) & $10.06^{\mathrm{b}}$ & $9.39^{\mathrm{b}}$ & $13.67^{\mathrm{a}}$ & 3.12 \\
Sperm cell concentration per ejaculate (x10 $/ \mathrm{ml})$ & $5.776^{\mathrm{a}}$ & $6.240^{\mathrm{a}}$ & $4.261^{\mathrm{b}}$ & 0.32 \\
Hypo-osmotic swelling test (\%) & $53.94^{\mathrm{a}}$ & $54.51^{\mathrm{a}}$ & $49.18^{\mathrm{b}}$ & 1.24 \\
\hline
\end{tabular}

G1and G2: Bulls received flaxseed oil 2 and 4\%/kg DMI, respectively. G3: Control

Data in the raw followed by different letters are significant at $\mathrm{P}<0.05$.

Table 4: Concentration of testosterone hormone $(\mathrm{ng} / \mathrm{ml})$ in blood serum as affected by flaxseed oil supplementation

\begin{tabular}{|c|c|c|c|c|c|}
\hline \multirow{2}{*}{ Time (month) } & \multicolumn{4}{|c|}{ Experimental group } & \multirow{2}{*}{ Overall means } \\
\hline & G1 & $\mathrm{G} 2$ & G3 & $\pm \mathrm{MSE}$ & \\
\hline 15 & 1.507 & 1.960 & 1.189 & 0.12 & $1.552^{\mathrm{c}}$ \\
\hline 16 & 2.340 & 2.633 & 2.328 & 0.10 & $2.434^{\mathrm{ab}}$ \\
\hline 17 & 2.474 & 2.263 & 2.023 & 0.12 & $2.253^{\mathrm{b}}$ \\
\hline 18 & 2.323 & 2.339 & 1.949 & 0.11 & $2.204^{\mathrm{b}}$ \\
\hline 19 & 2.541 & 3.084 & 2.082 & 0.11 & $2.569^{\mathrm{a}}$ \\
\hline 20 & 2.732 & 2.860 & 1.753 & 0.15 & $2.448^{\mathrm{a}}$ \\
\hline 21 & 2.736 & 2.860 & 2.121 & 0.14 & $2.572^{\mathrm{a}}$ \\
\hline Overall means & $2.774^{\mathrm{a}}$ & $2.954^{\mathrm{a}}$ & $2.241^{\mathrm{b}}$ & 0.13 & \\
\hline
\end{tabular}

G1and G2: Cows received flaxseed oil 2 and 4\%/kg DMI, respectively. G3: Control

Data in the raw followed by different letters are significant at $\mathrm{P}<0.05$. 


\section{Semen quality}

In the current study, flaxseed oil as a source of omega-3 fatty acids treatment significantly $(\mathrm{P}<0.05)$ increased ejaculate volume, sperm cell concentrations, mass motility (\%), live sperm $(\%)$ and sperm cell concentrations per ejaculate $\left(1 \times 10^{6} \mathrm{ml}\right)$ in $\mathrm{G} 2$ and $\mathrm{G} 3$ than in $\mathrm{G}$ (Table 3). Moreover, sperm abnormality (\%) was significantly lower in treated groups than in the control group by $26.41 \%$ in G1 and $31.31 \%$ in $\mathrm{G} 2$, respectively. This improvement in all semen characters could be attributed to flaxseed oil supplementation with its high content of linoleic and linolenic acids as good antioxidants. Supplementation of flaxseed oil also produced a great improvement of all semen characters of rams (31). Moreover, different ratios of omega-3/omiga-6 PUFA were reported to improve semen characteristic by elevating omega-3/omega-6 PUFA that increased sperm concentration and motility and to reduce the deformity rate of the sperm (7). In the rats diet appropriate ratio of omega-3/omega-6 PUFA improved semen quality and changes in hormone metabolism due to improving reproductive performance (32). The progressive motility was reported to be higher in frozen-thawed semen in the flaxseed oil treated group than in the fish oil group (33). Dietary supplemented with PUFA improved reproductive performance, development of testis, spermatogenesis, sperm of motility and viability in fresh or freeze semen sample in ruminant (34).

In the HOS test, incubation of sperm in hypo-osmotic media is necessary to estimate the plasma membrane covering the principle piece $(35,36)$. In the current study HOS test show that flaxseed oil supplementation to bulls significantly $(\mathrm{P}<0.05)$ increased the resistance of the sperm covering membrane to the hypo osmotic challenge in both G1 and G2 compared to the control G3 by about 9.68 and $10.84 \%$, respectively. The incorporation of DHA may be increased with Omega-3 treatment in the principle piece, facilitating sperm membrane stability against hypo-osmotic media (37).

The improvement of semen quality may be related to the supplementation with flaxseed oil with its PUFA the important molecules that serve as a source of energy and are critical components of the physical and functional structure of cells (38). Addition of OFA to animals diets improved sperm characteristics (39), increased sperm density and concentration per ejaculate $(40,41)$.

\section{Testosterone concentrations}

Testosterone is the key player in spermatogenesis and development reproductive tract in male (49). In this study, Friesian bulls serum testosterone concentrations were significantly increased by flaxseed oil treatments in $\mathrm{G} 2$ and G1 by 31.82 and $23.78 \%$ as compared to bulls in control (G3) (Table 4). The results agree with some study stated that omega-3 and 6 PUF may affect metabolism of important reproductive hormones. Testosterone concentration significantly increase in bulls supplemented with omega- 3 may be due to the adequate amount of unsaturated fatty acids such as linoleic and linolenic acids. These unsaturated fatty acids especially lenolenic could be converted or involved in the synthesis of cholesterol which is considered the precursor materials for testosterone synthesis (43). It was indicated that spermatogenesis and steroidogenesis in the avian testis are increased with the omega- 3 diets and this improvement dependent on the increase levels of FSH, LH and testosterone. However, O'Donnell et al. (45) reported that the concentrations of reproductive hormones and testosterone were positively higher related to presence of some important fatty acids and quality and morphology of sperm.

\section{Conclusion}

Dietary supplementation with omega-3 in male Frisian ration improved semen quality, testosterone level, lipid profile and immune function. Therefore the addition of flaxseed oil as a source of omega-3 is recommended to improve male animals semen quality and reproductively.

\section{Conflict of interest}

The authors declare that they have no conflict of interest. 


\section{References}

1. Sinclair AJ, Attar-Bashi NM, Li D. What is the role of a-linolenic acid for mammals? Lipids 2002; 37(12): 1113-23.

2. Mustafa AF, McKinnon JJ, Christensen DA, He T. Effects of micronization of flaxseed on nutrient disappearance in the gastrointestinal tract of steers. Anim Feed Sci Technol 2002; 95: 123-2.

3. Parodi PW. Cow's milk fat components as potential anti-carcinogenic agents. J Nutr 1997; 127(6) 1055-60.

4. Conners WE. Importance of n-3 fatty acids in health and disease. Am J Clin Nutr 2000; 71: 171S$-5 \mathrm{~S}$.

5. Wathes DC, Abayasekara DRE, Aitken RJ. Polyunsaturated fatty acids in male and female reproduction. Biol Reprod 2007; 77,190-201.

6. Abayasekara DR, Wathes DC. Effects of altering dietary fatty acid composition on prostaglandin synthesis and fertility. Prostaglandins Leukot Essent fatty acids 1999; 61: 275-87.

7. Estienne M, Harper A, Crawford R. Dietary supplementation with a source of omega-3 fatty acids increases sperm number and the duration of ejaculation in boars. Theriogenology 2008; 70: 706.

8. Mitre R, Cheminade C, Allaume P, Legrand P and Legrand AB. Oral intake of shark liver oil modifies lipid composition and improves motility and velocity of boar sperm. Theriogenology 2004; 62, 1557-66.

9. Safarinejad MR, Hosseini SY, Dadkhah F, Asgari MA. Relationship of omega-3 and omega-6 fatty acids with semen characteristics, and anti-oxidant status of seminal plasma: a comparison between fertile and infertile men. Clin Nutr 2010; 29:100-5.

shark liver oil modifies lipid composition and improves

10. Animal Production Research Institute. Animal Nutrition Scientifically and Practically. $1^{\text {st }}$ Ed. Animal Production Re-search Institute, Agricultural Research Center, Ministry of Agriculture, Dokki, Giza, Egypt 1997.

11. AOAC. Official Methods of Analysis. 18th ed. Assoc. Off. Anal. Chem., Gaithersburg, MD 2006.

12. Barth AD. Bull breeding soundness evaluation. The western Canadian association of bovine practitioners 2002.

13. Revell SG, Mrode RA. An osmotic resistance test for bovine semen. Anim Reprod Sci 1994; 36 77-86.
14. Abdelhady D, El-Abasy M, Abou-Asa S, Elbialy Z, Shukry M, Hussein A, Saleh A, El-Magd M. The ameliorative effect of Aspergillus awamori on aflatoxin B1-induced hepatic damage in rabbits, World Mycotoxin Journal 2017; 10(4): 363-73.

15. Almadaly E A, Farrag F A, Saadeldin I M, El-Magd M A, El-Razek I M A. Relationship between total protein concentration of seminal plasma and sperm characteristics of highly fertile, fertile and subfertile Barki ram semen collected by electroejaculation, Small Ruminant Research 2016; 144: 90-9.

16. El-Bayomi K M, Saleh A A, Awad A, ElTarabany M S, El-Qaliouby H S, Afifi M, El-Komy S, Essawi W M, Almadaly E A, El-Magd M A. Association of CYP19A1 gene polymorphisms with anoestrus in water buffaloes, Reproduction, Fertility and Development 2018; 30(3): 487-97.

17. Snedecor GW, Cochran WG. Statistical Methods. $7^{\text {th }}$ Ed. Iowa Univ. Press, Ames. Iowa, USA 1982.

18. Lee HJ, Khan MA, Lee WS, Kim HS, Ki KS, Kang SJ, Hur TY, Khan MS, Choi YJ. Growth, blood metabolites, and health of Holstein calves fed milk replacer containing different amounts of energy and protein. Asian-Australasian J Anim Sci 2008; 21(2):198-203.

19. Abu El-Hamd MA, El-Diahy YM, El-Maghraby MM, Elshora MA. Effect of flaxseed oil on digestibility, blood parameters, immuno-response and productive performance of suckling Friesian calves. J Anim Poult Prod Mansoura Univ 2015; 6(11): $663-75$.

20. Teama FEI, El-Tarabany AA. Physiological and biochemical response to Omega- 3 plus as a dietary supplement to growing goats under hot summer conditions. R Bras Zootech 2016; 45(4):17480.

21. Petit HV, Dewhurst RJ, Proulx JG, Khalid M, Haresign W, Twagiramungu H. Milk production, milk composition and reproductive function of dairy cows fed different fats. Can J Anim Sci 2001; 81: 263-71

22. Robinson, R.S.; P.G.A. Pushpakumara; Z. Cheng; A.R. Peters; D.R.E. Abayasekara and D.C. Wathes (2002). Effects of dietary polyunsaturated fatty acids on ovarian and uterine function in lactating dairy cows. Reproduction 2002; 124: 119-31.

23. Matson FH, Grundy SM. Comparison of effects of dietary saturated, monounsaturated and polyunsaturated fatty acids on plasma lipids and lipoproteins in man. J Lipid Res 1985; 26: 194-202.

24. Jones PJH, Ausaman LM, Croll DH, Feng JY, Schaefer EA, Lichtenstein AH. Validation of 
deuterium incorporation against sterol balance for measurement of human cholesterol biosynthesis. J Lipid Res 1998 39: 1111-7.

25. Fernandez ML McNamara DJ. Dietary fatmediated changes in hepatic apoprotein $\mathrm{B} / \mathrm{E}$ receptor in the guinea pig: effect of polyunsaturated, monounsaturated, and saturated fat. Metabolism 1989; 38: 1094-102.

26. Byers EM, Schelling GT. Lipids in ruminant nutrition. In: Church D.C. eds. The Ruminant Animal Digestion, Physiology and Nutrition. PrenticeHall, Inglewood Cliffs NJ USA 1988 pp. 298-310.

27. Petit HV. Digestion, milk production, milk composition and blood composition of dairy cows fed formaldehyde treated flaxseed or sunflower seed. J Dairy Sci 2003; 86: 2637-46

28. Nash, DM, Hamilton RMG, Hulan HW. The effect of dietary herring meal on the omega-3 fatty acid content of plasma and egg yolk lipids of laying hens. Can. J Anim Sci 1995; 75: 247-53.

29. Simopoulos AP. Omega-3-fatty acids and public health. Proc. Flax Council of Canada Conf. Flax, the Next Decade. 1996 Dec. 3-4. Winnipeg, MB. pp. 5-28.

30. Khan, N.A., Farooq, M.W., Ahmad, N., Cone, J.W. and Hendriks, W.H., 2015. Effect of species and harvest maturity on the fatty acid content and composition of tropical forages. J. Anim. Pl. Sci., 25: 739-46

31. Speake, BK, P.F. Surai PF, Rooke JA. Regulation of avian and mammalian sperm production by dietary fatty acids. In: Male Fertility and Lipid Metabolism. De Vriese SR, Christophe AB (eds). The American Oil Chemists Society Press, Urbana, USA 2003; pp 96-117

32. Yan, L., X.L. Bai; Z.F. Fang; L.Q. Che; S.Y. $\mathrm{Xu}$ and $\mathrm{D}$. Wu. Effect of different dietary omega3/omega-6 fatty acid ratios on reproduction in male rats. Lipids Health Dis. 2013; 12:33.

33. Moallem U, Neta N, Zeron Y, Zachut M, Roth Z. Dietary $\alpha$-linolenic acid from flaxseed oil or eicosapentaenoic and docosahexaenoic acids from fish oil differentially alter fatty acid composition and characteristics of fresh and frozen-thawed bull semen. Theriogenology 2015; 83, 1110-20.

34. Tran, L.V.; B.A.; Malla; S. Kumar and A. K. Tyagi. Polyunsaturated fatty acids in male ruminant reproduction. A Review. Asian-Australas J. Anim. Sci. 2017; (5): 622-37.

35. Brito, L.F.C.; A.D. Barth; S. Bilodeau Goeseels; P.L. Panich and J.P. Kastelic. Compari- son of methods to evaluate the plasma lemma of bovine sperm and their relationship with in vitro fertilization rate. Theriogenology $2003 ; .60: 1539-51$

36. Moce E, Graham JK. In vitro evaluation of sperm quality. Anim Reprod Sci 2008; 105:104 18.

37. Gholami H, Chamani M, Towhidi A, Fazeli MH. Improvement of Semen Quality in Holstein Bulls during Heat Stress by Dietary Supplementation of Omega-3 Fatty Acids.Int J Fertil Steril. Jan 2011; 4(4):160-7

38. Santos JEP, Bilby TR, Thatcher WW, Staples CR, Silvestre ET. Longc hain fatty acids of diet as factor influencing reproduction in cattle. Reprod. Dom Anim 2008; 43:23-30.

39. Robinson JJ, Ashworth CJ, Rooke JA, Mitchell LM, McEvoy TG. Nutrition and fertility in ruminant livestock. Anim. Feed Sci., Technol 2006; 126:259-76.

40. Rooke, JA, Shao CC, Speake BK. Effects of feeding tuna oil on the lipid composition of pig spermatozoa and in vitro characteristics of semen. Reprod 2001; 121:315-22.

41. Brinsko SP, Dickson DV, Charles CL, T.L. Blancharda TL, Dayc BC, Wilson ME. Effect of feeding a DHA-enriched nutriceutical on the quality of fresh, cooled and frozen stallion semen. Theriogenology 2005; 63:1519-27.

42. Gulliver CE, Friend MA, King BJ, Clayton ET. The role of omega-3 polyunsaturated fatty acids in reproduction of sheep and cattle. Anim Reprod Sci 2012; 131, 9-22.

43. Hafez ES. Reproduction in farm animals. $5^{\text {th }}$ ed Philadelphia lea \& Febig 1987.

44. Vizcarra JA, Kirb JD, Kreider DL. Testis development and gonadotropin secretion in broiler breeder males. Poult Sci 2010; 89(2):328-34.

45. O'Donnell L, McLachlan RI, Wreford NG, Robertson DM. Testosterone promotes the conversion of round spermatids between stages VII and VIII of the rat spermatogenic cycle. Endocrinology 1994; 135(6):2608-14.

46. Petit HV, Twagiramungu $\mathrm{H}$. Conception rate and reproductive function of dairy cows fed different fat sources. Theriogenology 2006; 66: 1316-24.

47. Dirandeh E, Towhidi A, Zeinoaldini S, Ganjkhanlou M, Ansari Pirsaraei Z, Fouladi Nashta A. Effects of different polyunsaturated fatty acid supplementations during the postpartum periods of early lactating dairy cows on milk yield, metabolic responses, and reproductive performances. J Anim Sci 2013; 91(2): 713-21. 
48. Hawkins DE, Niswender KD, Oss GM, Moeller CL, Odde KG, Sawyer HR et al. An increase in serum lipids increases luteal lipid content and alters the disappearance rate of progesterone in cows. J Anim Sci 1995; 73: 541-5.
49. McLachlan RI, O’Donnell L, Meachem SJ, Stanton PG, de Kretser DM, Pratis K, Robertson DM. Identification of specific sites of hormonal regulation in spermatogenesis in rats, monkeys and man. Rec. Prog. Horm. Res 2002; 57, 149-79. 